\title{
FECUNDITY OF ANT QUEENS IN RELATION TO THEIR AGE AND THE MODE OF COLONY FOUNDING
}

\author{
L. KELLER (1) and L. PASSERA (2)
}

(1) Musée Zoologique, Palais de Rumine, CP 448, 1000 Lausanne 17, Switzerland

(2) Laboratoire d'Entomologie, Université Paul Sabatier, 118, route de Narbonne, F 31062 Toulouse Cedex, France, U.A. C.N.R.S. 303

Reçu le 23 janvier 1989

Accepté le 15 juin 1989

\section{SUMMARY}

The change over time in the fecundity and weight of queens was investigated in three monogynous, independent colony founding species, Lasius niger, Camponotus ligniperda and $C$. herculaneus, and two polygynous dependent colony founding species, Plagiolepis pygmaea and Iridomyrmex humilis. Queens of the three species founding independently exhibited a similar pattern with a significant loss of weight between mating and the emergence of the first workers. In contrast, weights of queens of the species employing dependent colony founding remained more stable. Fecundity of queens founding independently increased slowly with time whereas fecundity of queens founding dependently reached the maximum level some weeks after the beginning of the first reproductive season. These results are discussed in relation to some differences in the life history (e.g., life-span) between queens utilizing independent and dependent colony founding.

\section{RESUME}

\section{Fécondité des reines de fourmis en relation avec leur âge} et le mode de fondation de la société

On a étudé dans ce travail les variations en fonction du temps de la fécondité et du poids des reines fondatrices de trois espèces monogynes à fondation indépendante (Lasius niger, Camponotus ligniperda, Camponotus herculeanus) et de deux espèces polygynes à fondation dépendante (Plagiolepis pygmaea et Iridomyrmex humilis). Les reines fondatrices des trois espèces à fondation indépendante montrent des similitudes avec une perte de poids significative entre le moment de l'accouplement et celui de l'émergence des premières ouvrières. A l'inverse, le poids des jeunes reines à fondation dépendante reste plus stable après l'accouplement. La fécondité des reines fondant de manière indépendante augmente lentement avec le temps, alors que celle des reines fondant de façon dépendante atteint son niveau maximal quelques semaines seulement après le début de la première saison d'activité. Ces résultats sont discutés dans le cadre des différences phénologiques (comme par exemple l'espérance de vie) qui apparaissent entre les reines pratiquant les deux types de fondation. 


\section{INTRODUCTION}

A colony of social insects may have a single functional, i.e., egg-laying queen (monogyny) or more than one queen (polygyny) WILson, 1974; HölLDOBLER and WILSON, 1977). Monogynous species generally exhibit high intercolonial aggression. In contrast intercolonial aggression is generally lower in polygynous species (HölLDOBLER and WILSON, 1977; KelLER and PAssera, 1989a).

Monogynous species generally employ independent colony founding i.e., after the nuptial flight, newly mated queens excavate a cell and rear the first brood in isolation without the help of workers. A few exceptions can be mentioned such as army ants which reproduce by colony fission (Franks and HölLDOBLER, 1987). In contrast, many polygynous species can not found new colonies without the help of workers (dependent colony founding) (KELLER, unpublished). In those species, young queens remain within the mother nest after mating or they enter a foreign colony of the same species. Foundation of new colonies generally occurs by budding or fission, a process in which one or several queens move out of the nest, accompanied by workers and establish a new colony.

A question of great interest is the adaptive value of polygyny vs. monogyny in the context of the evolution of sociality. Several authors have discussed the advantages of dependant and independent colony founding in relation to dispersal ability, probability, of successful colonization of a new habitat (Hölldobler and Wilson, 1977 ; Rosengren and Pamilo, 1983 ; Keller, 1988a) and relative investment of energy that each type of colony founding necessitates (Keller and PASSERA, 1988). In the case of independent colony founding, it is well known that queens have low fecundity during the founding stage (see BRIAN, 1983). After the emergence of the first workers, fecundity of queens regulary increases with time. This can be explained first, by the fact that food input in the colony depends on the number of workers, and second by the fact that the number of workers limits the quantity of brood which can be raised in the colony. In contrast to species with independent colony founding, species with dependent colony founding have young queens which are accompanied by a high number of workers immediately after mating. This raises the question of whether these queens rapidly reach a high level of fecundity after mating or, by contrast, if the fecundity of queens increases as a function of their age. To investigate this question, which is important in assessing the adaptive benefits of independent vs. dependent colony founding, we compared the change in the fecundity of queens in relation to age in five species of ants, three exhibiting independent colony founding and two employing dependent colony founding. 


\section{MATERIALS AND METHODS}

The fecundity of queens was investigated in three monogynous species, Lasius niger, Camponotus herculeanus, C. ligniperda (independent colony founding), and two polygynous species, Plagiolepis pygmaea and Iridomyrmex humilis (dependent colony founding) for the two first years of their life.

Monogynous species: L. niger is a monogynous species employing independent colony founding. Colony founding may occur either by haplometrosis (queens start a new colony alone) or by pleometrosis (several queens associate during founding) (WALOFF, 1957).

C. herculeanus and $C$. ligniperda are generally monogynous although some nests may contain up to three queens (HöLLDOBLER, 1962). In these two species, colony founding may also occur by haplometrosis or pleometrosis (HölLDOBLFR, 1962).

Polygynous species: Plagiolepis pygmaea is a polygynous species with a mean of 17 queens per colony (Mercier et al., 1985). In southern France, we have never observed queens founding new colonies claustrally. We therefore suspect that this mode of colony founding is absent or very rare in this species. New colonies probably result from budding and new queens are added by adoption of newly-mated queens after the mating flights occurring in mid-July.

I. humilis is a polygynous ant (NEWELL, 1909; MARKIN, 1970; KeILER, 1988b). In this species, workers are sterile (MARKIN, 1970; BARTELS, 1988); there is usually no nuptial flight by queens, mating occurs, in the nest (PASSERA and Keller, 1987; Passera et al., 1988b), and colony founding is accomplished by budding (NEwELl and BARBER, 1913; MARKIN, 1970).

\section{Experimental procedure}

Founding queens of L. niger were collected in June 1987 near Lausanne, Switzerland and those of $C$. herculeanus and $C$. ligniperda were collected just after their nuptial flight in early July close to the Marchairuz pass in the Jura mountains, Switzerland. Young queens of these three species were housed in small nests (see PASSERA et al., 1988a) and were fed three times a week with honey and mealworms as soon as the first workers emerged. The number of eggs, larvae, pupae and workers was counted and the queens weighed weekly for two years. All colonies of the three species were overwintered at $12 \pm 3^{\circ} \mathrm{C}$ for three months from the beginning of December to the end of February. There was high mortality in the three species. Only data from queens surviving to the end of the experiment were considered, i.e., 9 in $L$. niger and $C$. herculeanus each and 7 in C. ligniperda.

$P$. pygmaea colonies were collected near Toulouse, France, in early July before the yearly mating flight. They contained laying queens and sexual pupae. The ants were kept in small nests (see PASSERA, 1969) and maintained in a rearing room at $26.5 \pm 1^{\circ} \mathrm{C}$ during the experimental period and at $12 \pm 1^{\circ} \mathrm{C}$ during overwintering. After the emergence of the sexuals, mating flights occurred in a large experimental cage in the laboratory. The newly- inseminated queens shed their wings and returned to the nests. At this time, each queen was marked with a spot of paint. As a result of the return of the newly mated females, at the beginning of October, colonies contained both young queens less than four months old and old queens collected from the field, at least 16 months old. These colonies overwintered until March of the following year. Then, they were split into 24 units containing one "young" queens now 9 months old and 24 units containing one "old" queen being at least 21 months old. Each queen was 
nursed by $23 \pm 4$ workers. Since in this species the fecundity of individual queens is related to weight (MERCIER et al., 1985) we selected queens with similar weight: the mean weight of the young queens was $0.810 \pm 0.019 \mathrm{mg}$ while that of the old queens was $0.808 \pm 0.017 \mathrm{mg}$. During the first days following of the beginning of the experiment, the units were monitored daily in order to determine when the queens began to lay. Later, eggs were removed and counted at $7,14,21,28$ and 35 days after the beginning of the experiment. At the same time each queen and a random sample of 10 eggs from both young and old queens were weighed.

Colonies of $I$. humilis were collected in December 1986 in Port-Leucate near Perpignan in southern France. They were reared in conditions similar to those described by PASSERA et al. (1988a); the ants were maintained at a constant temperature of $28 \pm 2^{\circ} \mathrm{C}$ and fed with an artificial diet (see KELLER et al. in press). Under these conditions queenless units rear winged queens and males (PASSERA et al., 1988b). Mating soon occurs (5.1 \pm 2.0 days) after emergence (KeLleR and PASSERA, 1988; PASSERA et al., 1988b). Immediately after mating and dealation, 10 newly-inseminated queens were weighed, then housed individually in experimental units consisting of 700 workers. At 15,30 and 45 days after the beginning of the experiment, each queen was weighed and subjected to an oviposition. test (see KELLER, 1988a) : each queen was confined to a small vial containing a layer of damp plaster for 14 hours and the number of eggs laid was counted with the aid of a dissecting microscope. To compare the fecundity of newly-emerged queens to that of old queens, 12 old queens which were collected on 7 April 1987 at the same place as the other colonies were submitted to the same procedure. The age of these latter queens was unknown but it was close to one year since queens are produced yearly in late spring. Furthermore, most of them were probably not older than one year since ca. $90 \%$ of the queens are executed by workers in May just before the time of the production of new sexuals (KeLler et al., 1989).

\section{Statistical analysis}

All data were found to be normally distributed according to the Kolmogornov test. All means were therefore compared with the $t$-test.

\section{RESULTS}

\section{Species using independent colony founding}

The three species employing independent colony founding exhibited a similar pattern in the change in weight and fecundity. Data are therefore presented together for these' species. Egg-laying started rapidly after the mating flight (table $I$ ). The first larvae were produced first in $L$. niger then in the two Camponotus species (table $I$ ). Similarly, pupation of the first brood and emergence of the first workers occurred earlier in $L$. niger than in the two Camponotus species. In the two Camponotus species, $C$. ligniperda had the slower brood development, pupae and workers being observed ca. one week latter than in $C$. herculaneus. 
Table I. - First record of workers and each brood stage in the colonies of species exhibiting independent colony founding.

Tableau I. - Dates d'apparition des ouvrières et du couvain dans les colonies d'espèces avec fondation indépendante.

\begin{tabular}{lcccc}
\hline \multicolumn{1}{c}{ Species } & First eggs & First larvae & First pupae & First workers \\
\hline Lasius niger & $2.8 \pm 1.7$ days & 3rd week & 4th week & 5th week \\
\hline Camponotus herculaneus & $2.8 \pm 1.8$ days & 4th week & 5th week & 7th week \\
\hline Camponotus ligniperda & $2.1 \pm 1.3$ days & 4th week & 6th week & 8th week \\
\hline
\end{tabular}
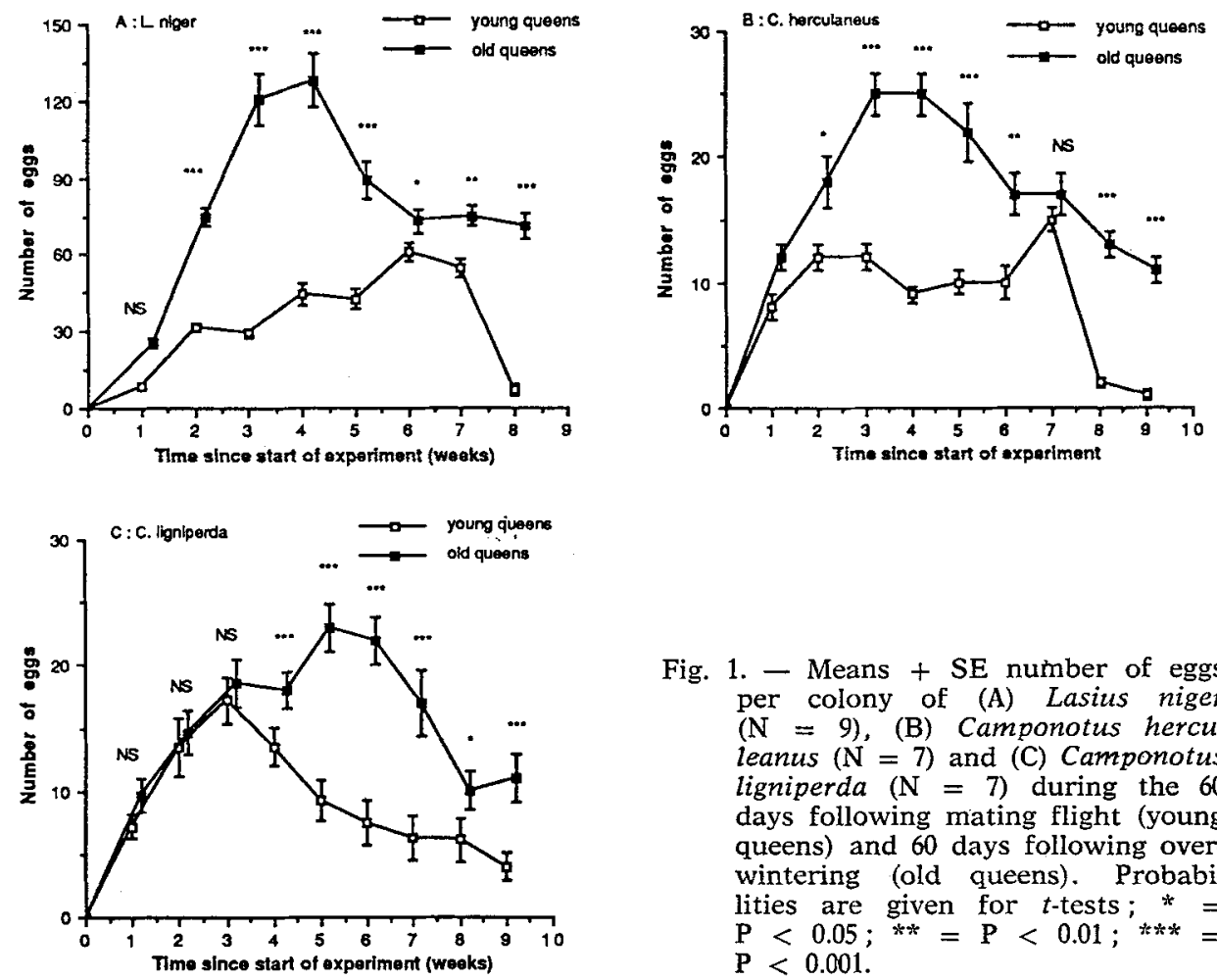

Fig. 1. - Means + SE number of eggs per colony of (A) Lasius niger $(\mathrm{N}=9)$, (B) Camponotus herculeanus $(\mathrm{N}=7)$ and $(\mathrm{C})$ Camponotus ligniperda $(\mathrm{N}=7)$ during the 60 days following mating flight (young queens) and 60 days following overwintering (old queens). Probabilities are given for $t$-tests; * = $\mathrm{P}<0.05 ; * * \mathrm{P}<0.01 ; * * *=$ $P<0.001$.

Fig. 1. - Nombre d'œufs moyen ( \pm erreur standard) comptés dans des sociétés de (A) Lasius niger $(\mathrm{N}=9)$, (B) Camponotus herculeanus $(\mathrm{N}=7)$ et $(\mathrm{C})$ Camponotus ligniperda $(\mathrm{N}=7$ ) pendant les 60 jours qui suivent le vol nuptial (jeunes reines) et pendant les 60 jours qui suivent l'hibernation (vieilles reines). Les probabilités sont données après application du test de $t ;^{*}=\mathrm{P}<0,05 ;{ }^{* *}=\mathrm{P}<0,01 ; * * *=$ $\mathrm{P}<0,001$. 
Queen fecundity and brood composition

In the three species, the number of eggs per colony regularly increased after colony founding (fig. 1). The maximum number of eggs were recorded at week 6 in $L$. niger, at week 7 in $C$. herculanteus and at week 3 in C. ligniperda. After having reached this maximum, egg number decreased in the three species and no more eggs were recorded in the colonies from weeks 15, 9 and 10 onwards for $L$. niger, $C$. herculaneus and $C$. ligniperda, respectively. The absence of eggs in the colonies resulted from the cessation of egg laying by queens until after overwintering.

Composition of the colonies after overwintering is given in table II. All colonies of the three species contained no eggs and no pupae. The number of larvae and workers was similar in the two species of Camponotus (t-test; NS). In $L$. niger the number of larvae and workers was far greater (t-test; $\mathrm{P}<0.001$ for both larvae and workers) than in the two species of Camponotus. After overwintering, queens rapidly started to lay eggs in the three species (fig. 1); the number of eggs per colony regularly increased in the three species and the maximum number of eggs were recorded in the censuses performed at weeks 4,4 and 5 for $L$. niger, $C$. herculaneus and $C$. ligniperda, respectively. In the three species, the number of eggs per colony was higher in the censuses performed after overwintering than in the corresponding ones performed after nuptial flight (fig. 1). The difference was significant for all comparisons except one in $L$. niger and $C$. herculaneus. In $C$. ligniperda, the number of eggs was also always higher after overwintering, but the difference was significant only for three censuses.

\section{Weight of queens}

After nuptial flight, queens of the three species experienced a drastic and continuous loss of weight up to the time of emergence of the first workers (fig. 2). Weight decreased from $27.6 \pm 2.6 \mathrm{mg}$ to $15.1 \pm 3.2 \mathrm{mg}$ (mean $\pm \mathrm{SD}$; paired t-test $\mathrm{P}<0.001$; decrease $45 \%$ ), $118.6 \pm 26.0$ to $76.3 \pm 24.0(\mathrm{P}<0.001$; decrease $36 \%)$ and $164.6 \pm 24.8$ to $139.0 \pm 17.1$ $(\mathrm{P}<0.001$; decrease $16 \%)$ in L. niger, C. herculaneus and C. ligniperda, res-

Table II. - Composition of the colonies after overwintering.

Tableau II. - Composition des colonies après l'hibernation.

\begin{tabular}{lcccc}
\hline \multicolumn{1}{c}{ Species } & $\begin{array}{c}\text { Number } \\
\text { of eggs }\end{array}$ & $\begin{array}{c}\text { Number } \\
\text { of larvae }\end{array}$ & $\begin{array}{c}\text { Number } \\
\text { of pupae }\end{array}$ & $\begin{array}{c}\text { Number } \\
\text { of workers }\end{array}$ \\
\hline Lasius niger & 0 & $38.4 \pm 14.7$ & 0 & $23.5 \pm 4.3$ \\
\hline Camponotus herculaneus & 0 & $5.3 \pm 3.8$ & 0 & $3.5 \pm 1.0$ \\
\hline Camponotus ligniperda & 0 & $7.1 \pm 2.8$ & 0 & $3.5 \pm 4.3$ \\
\hline
\end{tabular}



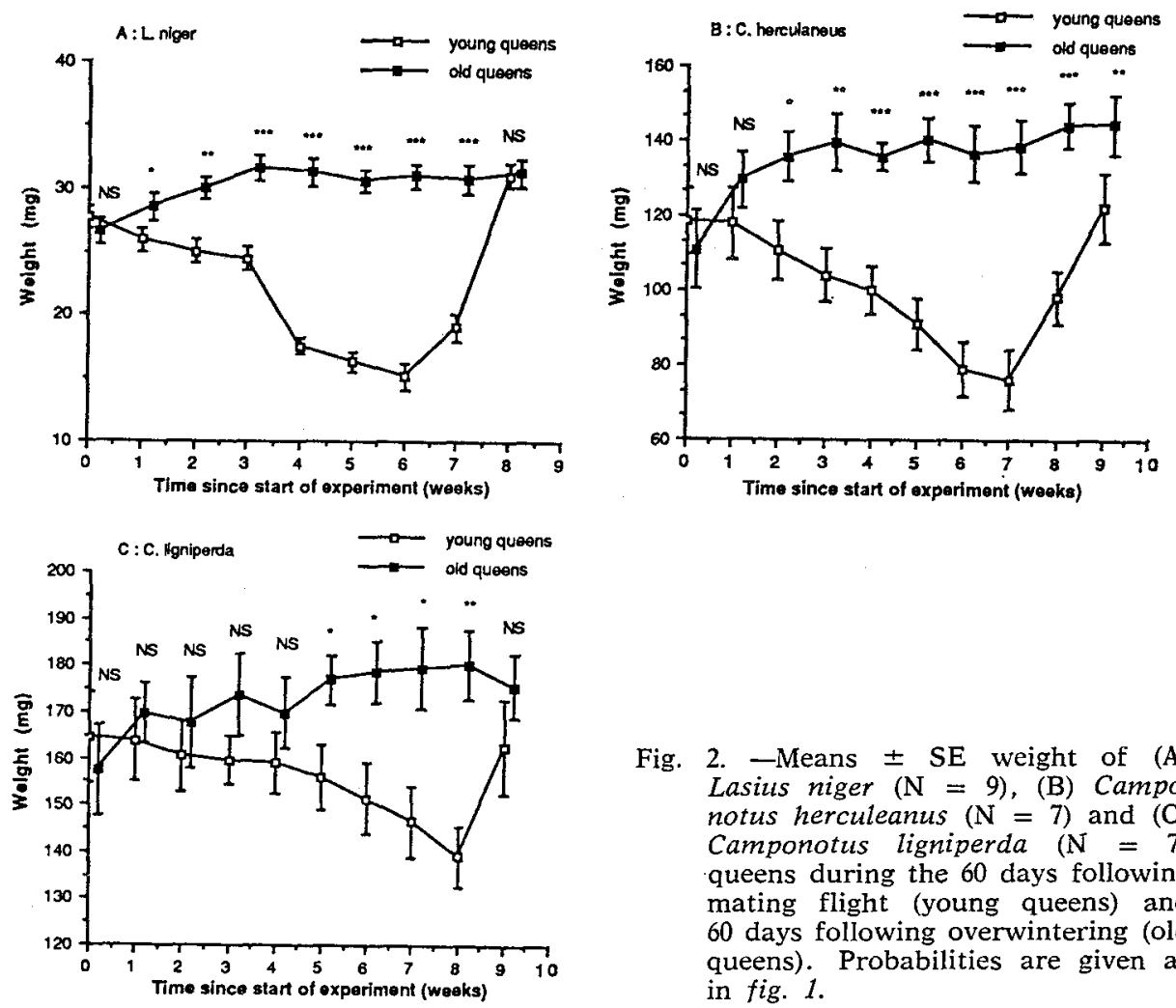

Fig. 2. -Means \pm SE weight of (A) Lasitus niger $(\mathrm{N}=9)$, (B) Camponotus herculeanus ( $\mathrm{N}=7$ ) and (C) Camponotus ligniperda $(\mathrm{N}=7)$ queens during the 60 days following mating flight (young queens) and 60 days following overwintering (old queens). Probabilities are given as in fig. 1.

Fig. 2. - Poids moyens ( \pm erreur standard) des reines de (A) Lasius niger $(\mathrm{N}=9)$, (B) Camponotus herculeanus $(\mathrm{N}=7)$ et $(\mathrm{C})$ Camponotus ligniperda $(\mathrm{N}=7)$ pendant les 60 jours qui suivent le vol nuptial (jeunes reines) et pendant les 60 jours qui suivent l'hibernation (vieilles reines). Les probabilités sont calculées comme dans la fig. 1 .

pectively. After the time of emergence of the first workers, the weight of queens of the three species increased up to a value slightly higher than that found at the time of mating flight. Weight of queens decreased slightly during the time of overwintering, but increased again after overwintering.

\section{Species using dependent colony founding}

\section{Plagiolepis pygmaea}

After transferring colonies from the room where they overwintered to the rearing room, queen mortality was $12.5 \%(\mathrm{~N}=24)$ for young queens and $25 \%(\mathrm{~N}=24)$ for old queens. However, this difference was not significant $\left(\chi^{2}=1.23\right)$.

Young queens $(\mathrm{N}=21)$ laid the first eggs $6.1 \pm 0.6$ days after overwintering, whereas old queens $(\mathrm{N}=18)$ laid ca. two days later $(7.9 \pm 0.6$ 
days; $\mathbf{P}<0.01)$. Eggs laid by the young queens were significantly heavier $(12.0 \pm 0.04 \mu \mathrm{g})$ than the ones laid by the old queens $(10.8 \pm 0.01 \mu \mathrm{g} ; \mathrm{P}<$ $0.01)$.

Fecundity of young queens was very similar to that of old queens except at weeks 1 and 5 where young queens had a higher fecundity (fig. $3 A$ ). Overall, the mean, number of eggs per colony recorded during the 5 censuses was $31.4 \pm 29.0$ for young queens and $17.8 \pm 16.7$ for old queens $(t=1.71$; NS). In this species, fecundity of queens is dependent on the number of nurses (PASSERA, 1972). Since in our experiments, the number of workers per colony was low $(23 \pm 4)$, this explains the relatively low fecundity of queens compared to that of the one observed in colonies nursed by a high number of workers (PASSERA, 1972).

Weight of old queens was not significantly different of that of young queens except at week 2 (fig. 4A).

\section{Iridomyrmex humilis}

During the 45 days of the experiment, the fecundity of young queens $(\mathrm{N}=10)$ was similar to that of the old ones $(\mathrm{N}=12)$ (fig. $3 B)$ and the total number of eggs laid by young queens and old queens was similar (11.9 \pm 8.1 , respectivly; NS).

In contrast, young queens weighed less than the old ones, this difference being signifisant for all weeks ( $f i g .4 B$ ).
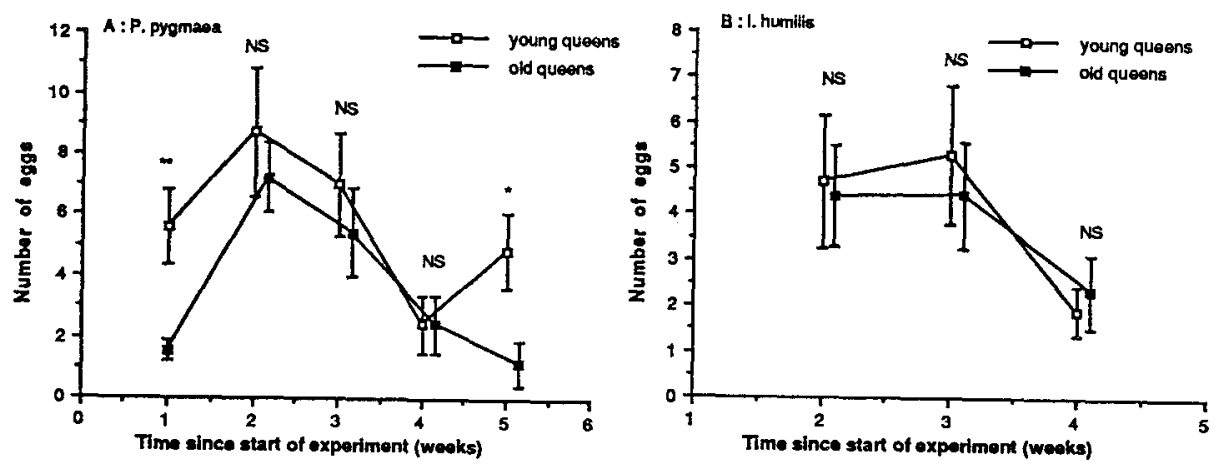

Fig. 3. - (A) Means \pm SE number of eggs per colony of Plagiolepis pygmaea containing young queens less than 9 months old (White squares, $N=21$ ) and old queens being one year older (black squares, $N=18$ ). (B) Means \pm SE fecundity of Iridomyrmex humilis newly mated queens (white squares, $\mathrm{N}=10$ ) and old queens about one year old (black squares, $N=12$ ). Probabilities are given as in figure 1 .

Fig. 3. - (A) Nombre d'œufs moyen ( \pm erreur standard) comptés dans des sociétés de Plagiolepis pygmaea contenant une jeune reine âgée de moins de 9 mois (carrés blancs, $N=21$ ) et une vieille reine âgée d'au moins un an (carrés noirs, $N=18$ ). (B) Fécondité moyenne ( \pm erreur standard) de reines nouvellement fécondées d'Iridomyrmex humilis (carrés blancs, $\mathrm{N}=10$ ) et de reines vieilles âgées d'environ un an (carrés noirs, $N=12$ ). Les probabilités sont calculées comme dans la figure 1 . 

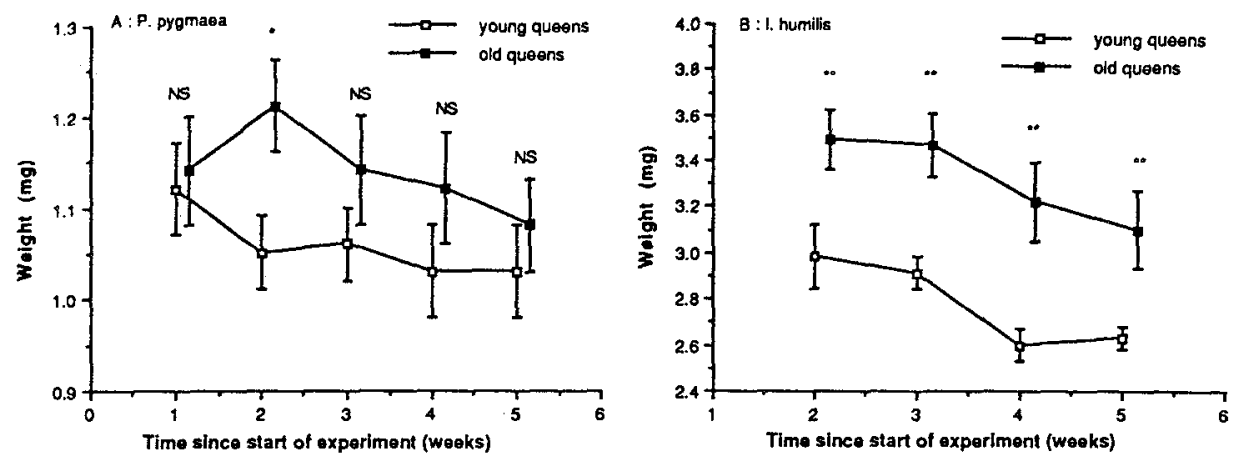

Fig. 4. - Means \pm SE weights of: (A) Plagiolepis pygmaea young queens less than 9 months old white squares, $N=21$ ) and old queens being one year older (black squares, $\mathrm{N}=18$ ): (B) Iridomyrmex humilis newly mated queens (white squares, $N=10$ ) and old queens about one year old (black squares, $N=12$ ). Probabilities are given as in figure 1.

Fig. 4. - Poids moyens ( \pm erreur standard) de: (A) jeunes reines de Plagiolepis pygmaea âgées de moins de 9 mois (carrés blancs, $\mathrm{N}=21$ ) et de vieilles reines âgées d'au moins un an (carrés noirs, $\mathrm{N}=18$ ). (B) reines d'Iridomyrmex humilis nouvellement fécondées (carrés blancs, $N=10$ ) et de vieilles reines âgées d'environ un an (carrés noirs, $\mathrm{N}=12$ ). Les probabilités sont calculées comme dans la figure 1 .

\section{DISCUSSION}

For queens of the three species with independent colony founding, the number of eggs laid increased regularly during the first weeks after the mating flight and then decreased when the first larvae hatched. This pause in egg-laying during the growth of the first brood is well-known in independent colony founding ants; it has been observed by PoLdi (1963) in Tetramorium caespitum, MaRKIN et al. (1972) in Solenopsis invicta ONOYAMA (1981) in Messor aciculatus and KITAMURa (1984) in Formica (Serviformica) japonica. This decrease in egg number may result either from oophagy of eggs by larvae and/or pheromonal inhibition of queen fecundity by larvae.

After overwintering, the pattern was similar to the founding stage with a rapid increase in egg number followed by a decrease. However, in all three species, the number of eggs in the colony increased at a faster rate and reached a higher number after overwintering than just after mating. Similar results have been found in other species with independent colony founding; in Myrmica rubra (BRIAN, 1957), Odontomachus haematodes (Colombel, 1970), Solenopsis invicta (MARKIN et al., 1973; LofGren et al., 1981), Messor ebeninus (TOHMÉ, 1975) and M. barbarus (CERDAN and DÉlye, 1987), fecundity of queens was found to increase as a function of their age and age of the colony. Similarly, in Leptothorax nylanderi there is a cons- 
tant increase in the number of larvae present during the first 7 years of colony life (Plateaux, 1986). All these data are in agreement with histological and anatomical observations on queens of Camponotus lateralis (PALMA-VALLI and DÉLYE, 1981) showing that the number of follicles per ovary increased with the age of the queen from 2 to 8 in young queens ( 1 to 3 years old) to over 20 in old queens ( 5 to 6 years old).

Generally speaking, this increase of queen fecundity and brood quantity in colonies as a function of queen and colony age is linked to the exponential growth of the colonies during the first years of their life (see BRIAN, 1965 and ElMES, 1965 and Elmes, 1973). Fecundity of queens is probably dependent on the number of workers which can feed them and care for the brood. In this respect, it is worthwhile to mention the higher increase of egg number/colony after overwintering (as compared to the time after the mating flight) in $L$. niger than in the two Camponotus. This higher increase probably resulted from the higher number of workers in the L. niger at the end of overwintering.

The pattern exhibited by the dependent founding species $P$. pygmaea and $I$. humilis contrasts sharply with that found in the independent founding species. I. humilis queens reached very early, i.e., less than two weeks after emergence, their maximal fecundity. Similarly, fecundity, of young $P$. pygmaea queens, only a few month old, was at least equivalent, if not higher, than that of queens one year older. These data suggest that in contrast to the queens with independent colony founding, newly-mated queens of species utilizing dependent colony founding are able to reach their maximal rate of egg output when they are very young : a few weeks old for I. humilis, and a few months old for $P$. pygmaea. However, the scarcity of research conducted on the fecundity of young dependently founding queens prevents generalisation. EDWARDS (1987) obtained different results in Monomorium pharaonis. Fecundity of young queens was far inferior to that of older queens. Similarly, young queens of Myrmica rubra are less fecund than older ones (BRIAN, 1988). However, it is necessary to mention that queens of these two species present some pecularities; Monomorium pharaonis queens exhibit a life-cycle clearly separated into three distinct periods characterized by a change in their inhibitory power over sexual production. Fecundity of queens may therefore depend on this cycle. Gynes of Myrmica rubra may either found new colonies independently by non claustral colony founding or join an incipient nest (G.W. ELMES pers. com.). This species may therefore not be a typical dependent colony founding species.

Queens of species with independent and dependent colony founding also differed drastically in weight change over time. During the first weeks of colony founding prior to the emergence of the first workers, there was a significant drop in weight for queens founding independently. This drop resulted from the catabolism of the flight muscles and large fat reserves that gynes accumulated prior to nuptial flight. At swarming, fat content repre- 
sents 51,43 and $46 \%$ of the dry weight of gynes of L. niger, C. herculaneus and C. ligniperda, respectively (KelleR and PASSERA, $1989 \mathrm{~b}$ ). These fat reserves provide the energy needed by queens to feed themselves and the first brood until the first workers start foraging. In contrast, queens of $P$. pygmaea and $I$. humilis did not lose weight during the first period of their reproductive activity. This can be explained by the fact that soon after mating, these queens are immediately fed by workers. In this respect, it should be mentioned that gynes founding dependently do not accumulate large amounts of fat prior to mating (Keller and PASSERA, $1989 \mathrm{~b}$ ). For example, fat constitutes only $25 \%$ of dry weight of mature gynes of $I$. humilis (Keller and Passera, 1988 ; Keller and Passera, 1989 b).

The weights of queens of species founding independently increased rapidly after the emergence of the first workers. At the time of overwintering, their weight was similar to that at the time of the nuptial flight. Dissection of queens showed that this increase in weight resulted at least partially from the development of the ovaries and storage of new fat reserves (KELLER and PASSERA, unpublished data). After overwintering, the weight of queens further increased, but at a slow rate, being probably due mostly to ovary development.

Young queens of $I$. humilis were significantly lighter than old ones. In I. humilis, fecundity of queens is linked to their weight, heavier queens having a higher fecundity (KELLER, 1988b). Our results therefore seem contradictory since old queens were heavier but had similar fecundity to young ones. One possible explanation is that laboratory conditions may have influenced the process of fat accumulation. Young queens which underwent all of their maturation in the laboratory may have had less opportunity to accumulate fat reserves in comparison to the old queens which were collected in the field. In $P$. pygmaea, there was only little difference between young and old queens both for weight and fecundity.

Considering the reproductive potentiality of the queens must take into account their life-span. Queens of $L$. niger have been observed to live more than 28 years (KuTTER and STUMPER, 1969). One colony of Camponotus ligniperda was still alive after 7 years of observation (KeLLER unpublished data). Although young colonies of $C$. ligniperda may occasionally contain several queens (HöLLDOBLER, 1962), we have never found more than one queen in mature colonies (KELLER unpublished data), suggesting that the queen of the above mentionned colony has been alive for more than 7 years. While we should remain cautious because most data come from laboratory observations, a survey of the literature seems to indicate that long life-spans of mated queens may be a common feature of monogynous independent founding species. The survivorships of queens was at least 5/6 years in Camponotus lateralis (Palma Valli and Délye, 1981), 5/6 years in several Myrmecia (HASKINS and HASKINS, 1980), 10 years in Ectatomma quadridens (D. FRESNEAU 
and J.P. LACHAUD, pers. com.), 9 years in Ectatomma ruidum (HASKINS and Haskins, 1980), Messor semirufus (ToнmÉ and ToHMÉ, 1978) and Lasius alienus (JANET, 1904), 10 years in Apnaenogaster picea (HASKINS, 1960), 11 years in Camponotus perthensis (HaskINS and HaskINs, 1980), 12.5 years in Rhytidoponera purpurea (HASKINS and HaSKINS, 1980), 11 to 20 years in several Leptothorax species (Plateaux, 1986), 17/18 years in Stenamma westwoudi (DONISTHORPE, 1936), 20 years in Crematogaster scutellaris (J. CASEvITZWeUleRsSe, com. pers.) and at least 22.5 years in Lasius flavus (PRESCoti, 1973). Similarly, physiological studies by determining sperm depletion in spermatheca gave an approximation of $6 / 7$ years for the mean life span of queens in the monogynous form of Solenopsis invicta (TschINKEL, 1987).

The life-spans of queens from polygynous dependent colony founding species seem to be shorter. Queens have been estimated to live less than one year in Monomorium pharaonis (PeacoK and Baxter, 1950 ; PetersenBRAUM, 1975), 4.5 years in Odontomachus haematodes (HASKINS and HASKINS, 1980 ), and probably less than 2 years in Wasmania auropunctata (P. UlloAChacon and D. Cherix, pers. com.). According to Elmes (1980) it is very difficult to maintain Myrmica queens in the laboratory for more than one season. Empirical data suggest that in the field, the queens of Myrmica sulcinodis may live 4/5 years (ELMES, 1987). The life-span of most queens of. $I$. humilis is less than one year, resulting from a massive regicide that occurs each year at the beginning of the reproductive season (Keller et al., 1989). No data are presently available concerning the life-span of $P$. pygmaea queens but it should be recalled that in the experiment reported here the mortality was estimated at $25 \%$ for old queens at the end of overwintering. It is reasonable to interpret these data as the result of a rather short life-span of queens in this species.

Thus, a major difference in the life history of queens using dependent and independent colony founding may be a shorter life span a shorter delay in reaching maximum egg-output for the former. Furthermore, since the ultimate factors influencing the fitness of queens is not the number of workers, but the number of sexuals produced, it should be mentioned that queens of species with independent colony founding have a chance to produce sexuals only when the colony is mature, i.e., only after several years (see Oster and WrLsoN, 1978), whereas queens employing dependent colony founding may produce sexuals when they are young, e.g., less than one year in I. humilis (Keller and PASSERA, unpublished data).

Finally, Nonacs (1988) developed a series of kin selection models in which in investigated factors which may favor polygyny in eusocial Hymenoptera. Polygyny was found to be favored by shorter life-span of queens. Our review on the litterature of life-span of queens of monogynous vs. polygynous species seems to support the models of NoNAcs. However, as mentioned by 
Nonacs himself, it is not possible to determine whether short-lived queens favor polygyny or, alternatively, if polygyny selects for short-lived queens.

AcKNowledgments. - Our special thanks are due to E. L. VARgo and two anonymous referees for helpful criticisms and for English language editing.

\section{References}

BARTELS P.J., 1988. - Reproductive caste inhibition by Argentine Ant queens : new mechanisms of queen control. Insectes Soc., 35,

BRIAN M.V., 1957. - The growth and development of colonies of the ant Myrmica. Insectes Soc., 4, 177-190.

Brian M.V., 1965. - Social Insect Populations. Academic Press, publ., London and New York, 135 p..

BRIAN M.V., 1983. - Social Insects. Ecology and Behavioural Biology. Chapman and Hall, publ., London, $377 \mathrm{p}$.

BRIAN M.V., 1988. - The behaviour and fecundity of queens of different ages in synthetic groups of Myrmica rubra L. with different worker populations. Insectes Soc., 35, 153-166.

Cerdan P., Delye G., 1987. - La fondation et les premières années du développement de la société de Messor barbarus (L.) (Hymenoptera, Formicidae). C. R. Acad. Sci. Paris, 305, série III, 31-34.

Colombier P., 1970. - Recherches sur la biologie et l'éthologie d'Odontomachus haematodes (Hym., Formicoïdea, Poneridae). Biologie des reines. Insectes Soc., 17, 199-204.

DonisthoRPE H., 1936: - The oldest insect on record. Entomol. Rec. and J. Var., 48, 1-2.

EDWARDS J.P., 1987. - Caste regulation in the pharoh's ant Monomorium pharaonis: the influence of queens on the production of new sexual forms. Physiol. Entomol., 21, 31-39.

Elmes G.W., 1973. - Observations on the density of queens in natural colonies of Myrmica rubra L. (Hymenoptera, Formicidae). J. Anim. Ecol., 42, 761-771.

ELmes G.W., 1980. - Queen numbers in colonies of ants of the genus Myrmica. Insectes Soc., $27,43-60$.

ElmES G.W., 1987. - Temporal variaton in colony populations of the ant Myrmica sulcinodis. 1. Changes in queen number, worker number and spring production. J. Anim. Ecol., 56, 559-571.

FRANKS N.R., HöLldobler B., 1987. - Sexual competition during colony reproduction in army ants. Biol. J. Linn. Soc., 30, 229-243.

HASKINS C.P., 1960. - Note on the natural longevity of fertile fernales of Aphaenogaster picea. J.N.Y. Entomol. Soc., 68, 66-67.

HASKINS C.P., HaSKINS E.F., 1980. Notes on female and worker survivorship in the archaic ant genus Myrmecia. Inectes Soc., 27, 345-350.

HöLldoBler B., 1962. - Zur Frage der Oligogynie bei Camponotus ligniperda Latr. und Camponotus herculeanus L. (Hym. Formicidae). Z. angew. Ent., 49, 337-352.

HöLldobleR B., WiLson E.O., 1977. - The number of queens: an important trait in ant evolution (Hym. Formicidae). Naturwissenschaften, 64, 8-15.

JaNET C., 1904. - Observations sur les fourmis. Ducourtieux et Gout, publ., Limoges, 144 p.

KeLLeR L., 1988a. - Evolutionary implications of polygyny in the Argentine ant, Iridomyrmex humilis (Mayr) (Hymenoptera: Formicidae): an experimental study. Anim. Behav., 36, 159-165.

KeLler L., 1988b. - Pouvoir attractif des reines de la fourmi d'Argentine, Iridomyrmex humilis (Mayr). Rôle de la polygynie et du statut physiologique des reines. Bull. Soc. Vaud. Sc. Nat., 79, 92-103.

Keller L., Cherix D., Ulloa-Chacon P. (in press). - Description of a new artificial diet for rearing ant colonies as Iridomyrmex humilis, Monomorium pharaonis and Wasmannia auropunctata (Hymenoptera: Formicidae). Insectes Soc. 
Keller L., Passera L., 1988. - Energy investment in gynes of the Argentine Ant Iridomyrmex humilis (Mayr) in relation to the mode of colony founding in ants (Hymenoptera: Formicidae). Int. J. Invert. Repr. and Dev., 13, 31-38.

Keller L., Passera L., 1989a. - Influence of the number of queens on netsmate recognition and attractiveness of queens to workers in the Argentine Ant Iridomyrmex humilis (Mayr). Anim. Behav., 733-740.

Keller L., Passera L. 1989b. - Size and fat content of gynes in relation to the mode of colony founding in ants (Hymenoptera; Formicidae). Oecologia, 80, 236-240.

Keller L., Passera L., Suzzoni J.P., 1989. - Queen execution in the Argentine Ant, Iridomyrmex humilis. Physiol. Entomol., 14, 157-163.

Krtamura S., 1984. - Colony foundation and development of Formica (Serviformica) japonica Motshulsky (Hymenoptera, Formicidae). Kontyu, 52, 411-426.

KutTer H., Stumper R., 1969. - Hermann Appel, ein leidgeadelter Entomologe (1892- 1966). Proc. 6th Int.. Cong. IUSSI, Bern, 275-279.

LOFGREN C.S., BANKS W.A., GLANCEY B.M., 1975. - Biology and control of imported fire ants. Ann. Rev. Entomol., 20, 1-30.

MARKIN G.P., 1970. - The seasonal life cycle of the Argentine ant Iridomyrmex humilis (Hymenoptera, Formicidae), in southern California. Ann. Entomot. Soc. Am., 63, 1238-1242.

Markin G.P., Collins H.L., Dillier J.H., 1972. - Colony founding by queens of the red imported fire ant, Solenopsis invicta. Ann. Entomol. Soc. Am., 65, 1053-1058.

Markin G.P., Dillier J.H., Collins H.L., 1973. - Growth and development of the red imported fire ant, Solenopsis invicta. Ann. Entomol. Soc. Am., 65, 1053-1058.

Markin G.P., Dillier J.H., CollinS H.L., 1973. - Growth and development of colonies of the red imported fire ant Solenopsis invicta. Ann. Entomol. Soc. Am., 66, 803-808.

Mercier B., Passera L., Suzzoni J.P., 1985. - Etude de la polygynie chez la fourmi Plagiolepis pygmaea Latr. (Hym. Formicidae). I. La fécondité des reines en condition expérimentale monogyne. Insectes Soc., 32, 335-348.

Newell W., 1909. - The life history of the Argentine Ant. J. Econ. Ent., 2, 174-192.

Newell W., Barber T.C., 1913. - The Argentine Ant. U.S.D.A. Bureau of Entomology Bull., $122,98 \mathrm{p}$

Nonacs P., 1988. - Queen number in colonies of social hymenoptera as a kin-selected adaptation. Evolution, 566-580.

ONOYAMA K., 1981. - Brood rearing by colony founding queens of the harvester ant Messor aciculatus. Kontyu, 49, 624-640.

Oster G.F., WilsoN E.O., 1978. - Caste and Ecology in the Social Insects. Princeton University Press, Princeton NJ, $352 \mathrm{p}$.

Palma-Valli G., Delye G., 1981. - Contrôle neuro-endocrine de la ponte chez les reines de Camponotus lateralis Olivier (Hyménoptères, Formicidae). Insectes Soc., 28, 167-181.

Passera L., 1969. - Biologie de la reproduction chez Plagiolepis pygmaea Latr. et ses deux parasites sociaux Plagiolepis grassei Le Masne et Passera et Plagiolepis xene St. (Hym. Formicidae), Annls Sci. nat. Zool., Biol. anim. 12c série, 11, 327-481.

Passera L., 1972. - Etude de quelques facteurs réglant la fécondité des reines de Plagiolepis pygmaea Latr. (Hym. Formicidae). Insectes Soc., 19, 369-388.

Passera L., Keller L., 1987. - Energy investment during the differentiation of sexuals and workers in the Argentine ant Iridomyrmex humilis (Mayr). Mitt. Schweiz. ent. Ges., $60,249-260$.

Passera L., Keller L., Suzzoni J.P., 1988a. - Control of brood male production in the Argentine Ant Iridomyrmex humilis (Mayr). Insectes Soc., 35, 19-33.

Passera L., Keller L., Suzzoni J.P., 1988b. - Queen replacement in dequeened colonies of the Argentine Ant Iridomyrmex humilis (Mayr). Psyche, 95, 59-65.

PeAcock A.D., BAxter A.T., 1950. - Studies in Pharaoh's ant, Monomorium pharaonis (L.). 3. Life history. Entomol. Mon. Mag., 86, 171-178.

Petersen-Braun M., 1975. - Untersuchungen zur Sozialen Organization der Pharaoameise Monomarium pharaonis (L.) (Hymenoptera, Formicidae). 1. Der Brutzyklus und seine Steurung durch Populationseigene Faktoren. Insectes Soc., 22, 269-292.

Plateaux L., 1986. - Comparaison des cycles saisonniers, des durées des sociétés et des productions des trois espèces de fourmis Leptothorax (Myrafant) du groupe nylanderi. Actes Coll. Insectes Soc., 3, 221-234. 
PoLDI B., 1963. - Studi sulla fondazione dei nidi nei Formicidi. I. Tetramorium caespitum L. Symp. gene. biolo. ital., 12, 132-199.

Prescott H.W., 1973. - Longevity of Lasius flavus (F.) (Hym. Formicidae) : a sequel. Entomol. Mon. Mag., 109, 124.

Rosengren R., PAMILo P., 1983. - The evolution of polygyny and polydomy in moundbuilding Formica ants. Acta Entomol. Fenn., 42, 65-77.

ToHME G., 1975. - Ecologie, biologie de la reproduction et éthologie de Messor ebeninus Forel (Hymenoptera, Formicoïdea, Myrmicidae). Bull. biot. Fr. Belg., 59, 171-251.

Tohme G., ToHMe H., 1978. - Accroissement de la société et longévité de la reine et des. ouvrières chez Messor semirufus (André) (Hym. Formicoïdea). C. R. Acad. Sci., Paris, 286, D, 961-963.

TSCHINKEL W.R., 1987. - Fire ant queen longevity and age estimation by sperm depletion. Ann. Entomol. Soc. Am., 80, 263-266.

WaLOFF N., 1957. - The effect of the number of the queens of the ant Lasius flavus (Fab.) (Hym. Formicidae) on their survival and on the rate of development in the first brood. Insectes Soc., 4, 391-408.

WILSON E.O., 1974. - The population consequences of polygyny in the ant Leptothorax curvispinosus. Ann. Entomol. Soc. Am., 67, 782-786.

Woon L.A., TsCHINkEl R., 1981. - Quantification and modification of worker size variation in the fire ant Solenopsis invicta. Insectes Soc., 28, 117-128. 